\title{
Mozambique Solar Thermal Energy Technologies: Current Status and Future Trends
}

\author{
Fernando Chichango *; Luís Cristóvão \\ Faculty of Environmental Engineering and Natural Resources, Zambeze University, Mozambique \\ chichango@gmail.com
}

\begin{abstract}
Mozambique's economy and population is growing fast and so its power needs. The country is amply endowed with abundant, high quality natural energy resource, but access to electricity is still a challenge to numerous people not to mention regularly blackout-related problems. Projected growth of urban and rural areas will represent a significant energy and climate challenge. The lack of access to energy is a major factor in the slow progress in attainment of the SDGs. Solar energy is seen as one of the most promising sources of energy, both for electricity supply and for thermal purpose. The country consistently presents a high level of solar radiation throughout the territory and throughout the year. The global horizontal irradiation varies between 1785 and $2206 \mathrm{kWh} / \mathrm{m}^{2} /$ year, but the contribution to the overall supply is still marginal. Understanding the proper technologies for harnessing solar thermal energy is fundamental for economic growth and social development. In this study, solar thermal technologies are comprehensively reviewed and barriers and opportunities are discussed. Although the country has enormous solar potential for the use of thermal energy, there are few systems installed (3MWP) with emphasis only on domestic multi-family force circulation systems, flat solar collectors and vacuum tubes in operation in single-family homes. Also, innovation of domestic thermal systems could help to mitigate the effects of climate change and reduce the costs of electricity tax in residences.
\end{abstract}

Keywords: climate change, electricity, thermal energy, solar collector, radiation

DOI: $10.7176 / \mathrm{JETP} / 11-5-02$

Publication date:October $31^{\text {st }} 2021$

\section{Introduction}

Socio-economic development is linked to energy demand. Energy supply has become the center of attention in the world. On the one hand, research focuses on the implementation of new energy sources, to ensure continuity and energy availability, and on the other hand, the new sources are implemented using sustainable technologies. The availability of energy resources throughout the universe is not uniform, some countries have plenty of nonrenewable sources, and others have a high energy potential from renewable sources even if it is not being exploited in its fullness. The intense use of non-renewable sources to meet the energy demand, imprinted by social and economic development threatens the depletion of these resources, but has also triggered the harmful effects on the environment, thus the need for sustainable use of these resources and the search for new renewable and clean sources. Mozambique faces two major energy challenges: inadequate access to energy and climate change. About $67 \%$ of population live and work in rural areas and $80 \%$ of the energy used in the country is in the form of traditional biomass. Comprehensive reviews on renewable energy (RE) in Mozambique have been conducted by Cuvilas, et al., (2010) and Cristóvão, et al., (2021). They pointed out that the exploitation of energy resources, in addition to geographical availability, is conditional on several factors of which they stand out - socio-cultural, economic, environmental, technological and local energy policies.

Solar energy is seen as one of the most promising sources of energy, both for electricity supply and for thermal purpose. The use of solar energy can take place in two ways: using solar panels to capture solar energy and transforming it into electrical energy (photovoltaic solar energy); or using solar panels for the purpose of heating water, for both residential, commercial and industrial use (solar thermal energy). Thermal solar energy has applications in residential, swimming pools, drying or industrial heating, and so on (ANELL, 2013). The country consistently presents a high level of solar radiation throughout the territory and throughout the year. The global horizontal irradiation varies between 1785 and $2206 \mathrm{kWh} / \mathrm{m}^{2} /$ year, but the contribution to the overall supply is still marginal. The Government of Mozambique has set as a target the installation of $0.1 \mathrm{~m}^{2}$ per capita of solar water heating systems by the year 2030, which will require a concerted effort of all stakeholders in the country, both public and private, as well as the development agencies (Arthur, et al., 2015). Although the performance of thermal energy sector is perceived as being below expectation, a number of energy policies have been developed, but the implementation has been limited by combination of factors that include: lack of skilled manpower, weak dissemination strategies, pricing distortion that places thermal energy at disadvantage and poor infrastructure. Thus, the purpose of this research is twofold as following: (a) to summarize the present status of solar thermal technologies, and (b) future trends of solar thermal technologies in Mozambique. 


\section{Solar Energy}

The SDG 7 aims to ensure reliable, sustainable, modern and affordable access to electricity for all (UN_CHRONIC, 2018). In the current formulation, this would require increasing the share of RE in the national energy mix and improvement of energy efficiency. For a country like Mozambique, solar energy could help sustainably reduce the energy gaps between the urban and rural areas (SDG 7), while responding to the climate change challenge (SDG 13). The country has substantial potential of solar resource that are fairly distributed throughout the country. This energy can be divided into two energy forms: photovoltaic and thermal systems. Photovoltaic systems are used to convert solar radiation to electricity using cells. While thermal systems are conversion of solar radiation to produce heat using solar collectors. The use of solar energy can be distinguished in direct and indirect, and also in active and passive systems. It is considered - direct use when solar energy only undergoes a transformation before being used by man, such as photovoltaic cells. And it is indirect use when solar energy needs more than one transformation to obtain usable energy. The production of electricity from steam turbine is an example of indirect use of solar systems.

Solar radiation is the energy emitted by the sun, which propagates through electromagnetic waves in the void or in material medium. Not all the radiation is absorbed by the Earth surface. The solar spectrum covers 3 wavelength bands that are styled according to their nature in: ultraviolet, visible and infrared radiation. Solar radiation provides annually to the Earth's atmosphere $1.5 \times 10^{18} \mathrm{kWh}$ of energy. Solar irradiation values are useful for sizing solar thermal energy systems.

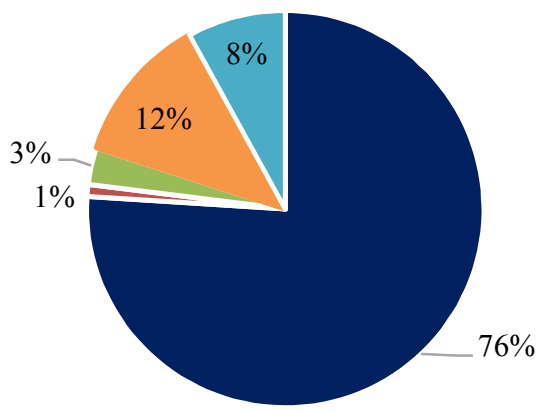

- Biofuels/waste - Coal - Natural Gas Hydro " Oil products

Figure 1: Balance of primary energy supply (source: EDM, 2018)

Although there is an increase in the use of REs in the country, solar energy in general, thermal energy in particular, are not yet relevant to be counted in the country's energy statistics, as shown in Figure 1. Thus, there are still huge opportunities to include other sources to diversify the energy mix.

\section{Thermal Solar Energy}

The primary purpose of thermal energy is to heat objects, liquid and gaseous fluids, the secondary is to produce electricity. The temperatures reachable in this process can reach up to $1000{ }^{\circ} \mathrm{C}$. 


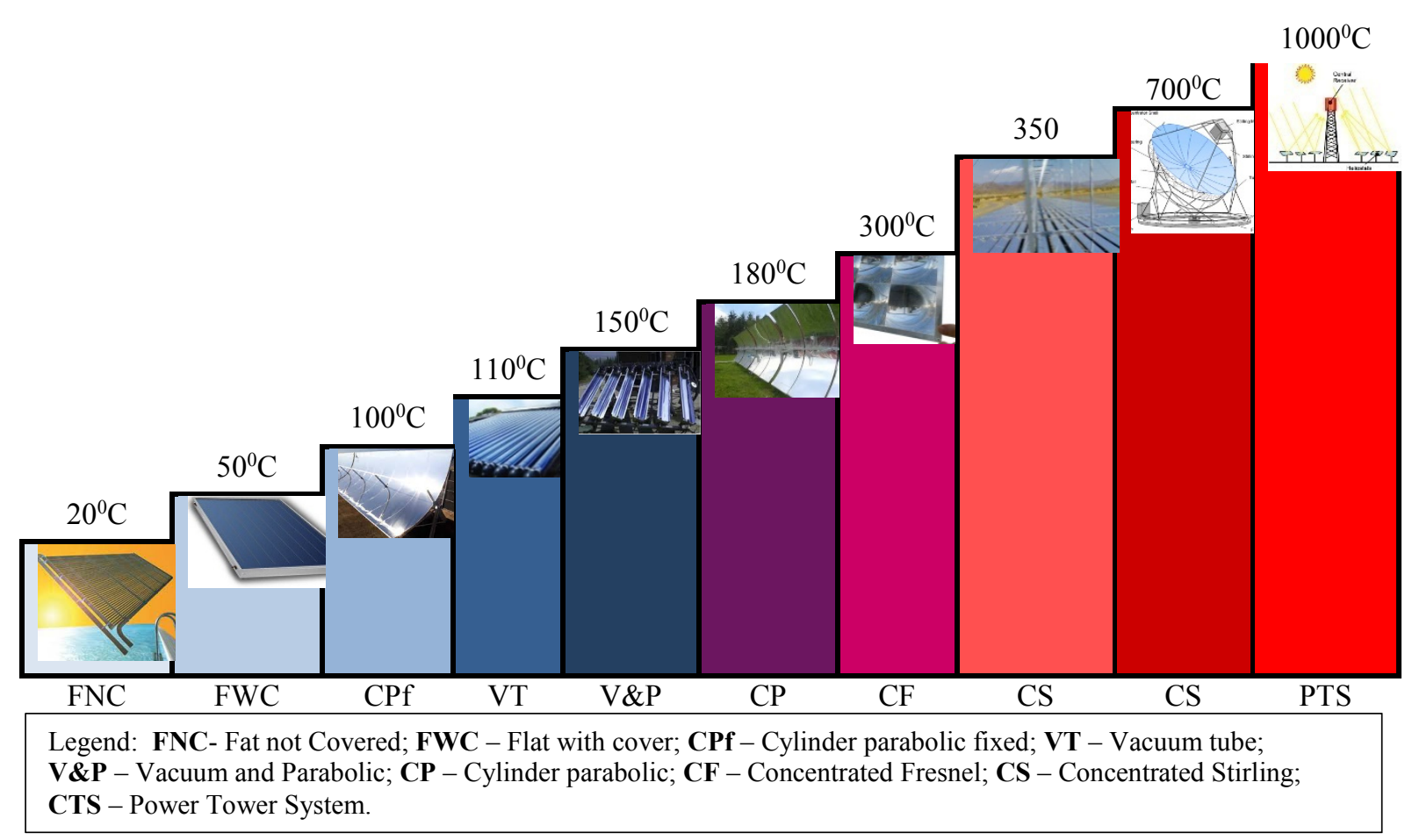

Figure 2: Operating temperatures of different thermal energy technologies

Figure 2 illustrates operating temperatures for different thermal collector technologies. Passive systems are often direct and in them there is no use of other means of energy to improve solar uptake. In active systems, there are mechanical, electrical or chemical equipment to improve the effectiveness of the solar community (Miller \& Miler, 2008).

Technologies with low thermic capacity $\left(20^{\circ} \mathrm{C}\right.$ to $\left.50^{\circ} \mathrm{C}\right)$ are used to heat water for sanitation in residences. Systems with capacity up to $350^{\circ} \mathrm{C}$ are applicate in industries to heat up water and air. Technologies with high thermic capacities are used indirect systems to produce electricity from steam turbine.

\section{Trends of Solar Thermal Systems in World Market}

In the world market, solar thermal systems have been experiencing trends in increasing installed and operating capacity. Growth of the capacity in operation of thermal systems in the world occurs worldwide. With greater prominence China with $69.9 \%$, holding higher percentage in relation to the sum of capacity of all countries in the world, as shown in Figure 3. By the end of 2017, an installed capacity of 389.7 TWh totaling 676.4 million square meters of collector's area was in operation worldwide (SHW, 2019).

The country with the most prominence in installed capacity in operation is China (334.5 GWth) and Europe $(54.3 \mathrm{GWth})$, which together represent $81.7 \%$. The remainder $(18.3 \%)$ is attributed to the group of other countries.

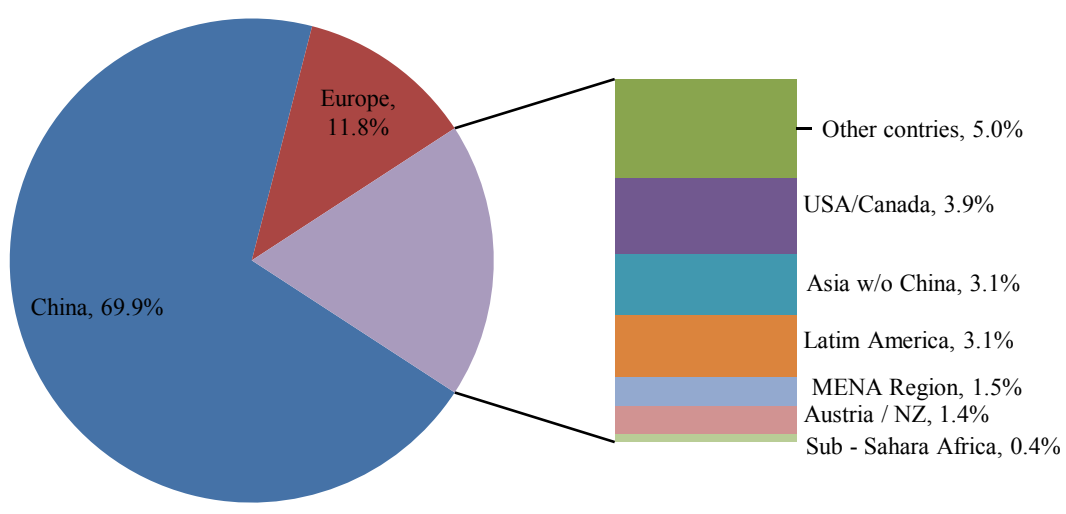

Figure 3: Distribution of installed operating capacity of solar thermal system in the world. Source: (SHW, 2019) 


\section{Current Status and Future Trends Solar Energy Technologies in Mozambique}

The development of solar thermal energy in the country is supported by the national policies patent in the energy strategies ("Resolution 10/2009 of 14 June") and in the Policies of New and Renewable Energy Development ("Resolution 62/2009 of 14 October") which both point to thermal solar energy as a key area for National development.

The basis for support for solar thermal energy exploration initiatives was pointed to the existing solar thermal potential at the level of the entire national territory with an average annual radiation of 1700 to $2200 \mathrm{kWh} / \mathrm{m}^{2}$. Another factor that drove the search for new alternative sources was the economic development of the country, which brought with it a growing energy demand.

The aluminum industry and the heavy sands of Moma and Chibuto are some examples pointed out as challenges for electricity supply. The vision of the Government of Mozambique is to popularization of the use of solar thermal energy in all country. Therefore, it established in a projection of 34 million inhabitants by 2030 a target of $0.1 \mathrm{~m}^{2}$ of solar collector per inhabitant, Figure 4.

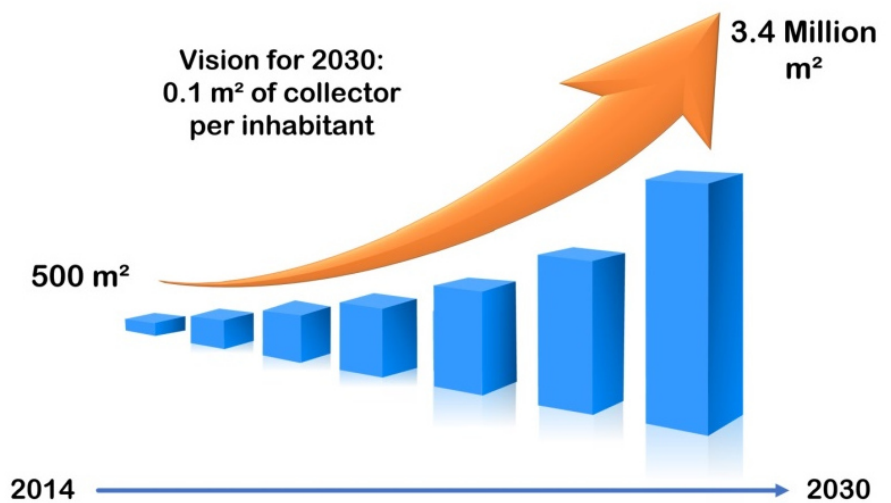

Figure 4: Solar thermal system expansion by 2030. Source: (Arthur, et al., 2015)

The SOLTRAIN Project (of the Southern African Solar Thermal Training and Demonstration Initiative) currently coordinated by the Maluana National Science and Technology Parks Company, it was one of the pioneers in the national implementation of the incentive measures for the popularization of solar thermal systems in Mozambique.

Through the SOLTRAIN project, the country benefited from the installation of 4 solar thermal systems: Ndlavela Women's Jail in Matola, Psychiatric Hospital. The SOLTRAIN Roadmap report present more approach and details about this issue. By the end of 2018, Mozambique had an installed and operational capacity of 2 MWth composed of $0.1 \mathrm{MWth}, 0.3 \mathrm{MWth}$ and 1.2 MWth for collectors without cover, flat and evacuated pipe, respectively (Weiss \& Dur, 2019).

The energy produced by these systems is completely free and requires virtually no maintenance. Solar systems save up to $40 \%$ of the cost of electricity. Thermal energy has a high social and economic impact in areas without the electricity grid, with greater phase when applied to absorption refrigeration systems in Community units for the conservation of fish. It is also highly economical for food industries and in product conservation.

Although many studies have indicated social, economic and environmental advantages in the use of solar thermal systems, there are conditions that prevail to the massive use of these environmentally friendly systems. According to Arthur et al., (2015) the challenges in the massive expansion of solar thermal systems in Mozambique are listed below:

$>$ Low level of consumer awareness, leading to low market demand, due to lack of information about the technologies, their availability and their performance. In addition, there is widespread scepticism about the performance and reliability of solar thermal energy technologies;

$>$ Few or almost non-existent installation/manufacturing sites, distribution, installation and maintenance of solar thermal technologies. This makes the country rely on more expensive imported systems and, consequently, low market penetration levels due to weak purchasing power;

$>$ Lack of adequate financing schemes and subsidies to start the spread of renewable technologies;

$>$ Late start of renewable energy training programs for technicians and professionals in schools;

$>$ Inadequate legislation and public leadership in the implementation of renewable energy technologies in the country;

$>$ Low level of access to the electricity grid and water supply in rural areas. The thermosiphon systems require that the thermal accumulator be at higher level of the solar collector, so the water must have sufficient pressure for its elevation.

The adoption of thermal and domestic water heating systems is delayed by the needs for quality water supply 
network and electricity grid. Another important factor is the high cost of systems. According to the National Science and Technology Park Company E.P, a company coordinating the promotion of solar thermal systems in Mozambique through the SOLTRAIN Project, the cost of the system is $29,529.00 \mathrm{MZN} / \mathrm{m}^{2}$, the cost that corresponds to more than 6 times the current minimum wage in the country.

An average Mozambican family consists of 4 to 7 members. With this requires on average $45 \times 7=315 \mathrm{~L}$ of hot water, based on basic calculations would require collector with $5 \mathrm{~m}^{2}$. With this coefficient, the total cost of the system would be approximately 150,000 MZN equivalents to \$2,142.85 (\$1=70MZN@Moz Bank13/08/2021). In the following are presented the possible alternatives actions for the mitigation of the imperatives for the adoption of thermal systems:

$>$ Cluster intervention in the promotion of thermal systems since the government from the ministries that oversee the water, energy, land and finance sector. And the research institutions, manufacturing companies and introduction to the introduction of clear and incentives policies.

$>$ Promotion of thermal systems manufacturing companies.

$>$ Promotion of capacity building in the area;

$>$ Development of systems with alternative materials accessible to the reach of all.

The approval of the New and Renewable Energy Development Strategy (EDENR) for the period of 2011 2025, created a great boost and legal support for the reach of the "Green Future". The same document defines strategic lines of Renewable Energy in isolated and off grid systems (EDENR - FR). The lines contain typical energy applications requiring energy services in isolated energy systems (EIS). The energy application of the solar thermal system as the primary source in EDENR - FR fits in the following needs: Refrigeration; Water heating.

\section{Conclusion}

Mozambique has a high solar potential for the use of thermal energy. This resource of energy can contribute to the reduction in overall consumption of electricity in Mozambique, especially in domestic sector, favouring the supply of electricity for industrial development. Environmentally, it can reduce the use of woody biomass in rural areas. However, there is a need action in cluster to reduce the imperatives of expansion of thermal systems in Mozambique. For the rural areas, isolated from the network, adoption is more imperative due to system constraints in relation to the water circuit. There is a need for innovation of domestic thermal systems to reduce costs and operation mechanisms independent of the water supply network. Also, it was noted that the cost of thermal systems still exceeds the purchasing capacity of most Mozambicans.

\section{Acknowledgements}

The authors express their gratitude to the Austrian Development Cooperation - APPEAR for providing financial support through the Capacity Building for Renewable Energy Technologies in Mozambique project.

\section{Reference}

1. ANELL, 2013. REPORT, Brasil: Centro de Documentação - CEDOC; Agência Nacional de Energia Elétrica (Brasil).

2. Arthur, F., Cumbe, F., Nhumaio, G. \& Saide, A., 2015. Solar Thermal Technology Raodmap. s.l.:s.n.

3. Cekirge, H. M. \& Elhassan, A., 2015. A Comparison of Solar Power Systems (CSP): Solar Tower (ST) Systems versus Parabolic Trough (PT) Sys. Volume Vol. 3, No. 3, 2015, pp. 29-36. doi: 10.11648/j.ajee.20150303.11.

4. Cristóvão, L., Chichango, F., Massinga, P. \& Macanguisse, J., 2021. The Potential of Renewable Energy in Mozambique: An Overview. pp. p30-37.

5. Curvilas, C., Jirjis, R. \& Lucas, C., 2010. Energy situation in Mozambique: A review. Elisevier.

6. EDM, 2018. Integrated Master Plan, s.l.: s.n.

7. Miller, R. \& Miler, M. R., 2008. Refrigeração e ar condicionado. São Paulo: Ltc - Livros Técnicos e Científicos.

8. Rosa, A. D., 2013. Fundamentals of Renewable Energy Processes. s.1.:Copyright (C) 2012 Elsevier Inc. All.

9. SHW, 2019. SOLAR HEAT WOULDWIDE. Global Market Development and Trends in 2018, Detailed Market Figures 2017, p. 83.

10. UN_CHRONIC, 2018. Organizacao das Nacoes Unidas - Agenda 2030. [Online] Available at: https://www.un.org/en/chronicle/[Accessed 12 Julho 2021].

11. Weiss, W. \& Dur, M. S. -., 2019. SOLAR HEAT WOULDWIDE. Global Market Development and Trends in 2018, Detailed Market Figures 2017, p. 83. 